\title{
Mean Subpubic Angle of Patients Visiting Department of Radiodiagnosis of a Tertiary Care Hospital: A Descriptive Cross-sectional Study
}

\author{
Ruku Pandit, ${ }^{1}$ Aarati Adhikari, ${ }^{2}$ Hari Prasad Upadhyay ${ }^{3}$ \\ 'Department of Anatomy, College of Medical Sciences and Teaching Hospital, Bharatpur, Chitwan, Nepal, \\ ${ }^{2}$ Department of Radiodiagnosis, College of Medical Sciences and Teaching Hospital, Bharatpur, Chitwan, Nepal, \\ ${ }^{3}$ Department of Statistics, Birendra Multiple Campus, Bharatpur, Chitwan, Nepal.
}

\section{ABSTRACT}

Introduction: The subpubic angle in the pelvis is most often used to estimate the sex with a higher degree of accuracy. Despite the anthropological and obstetric importance of the subpubic angle, only a few studies exist in the Nepalese population. The objective of this study was to determine the mean subpubic angle of the patient visiting the department of radiodiagnosis of tertiary care hospital.

Methods: This was a descriptive cross-sectional study comprising 332 pelvic digital radiographs of the patients visiting the department of radiodiagnosis of a tertiary care center from March to August, 2021. Ethical approval was taken from the Institutional Review Committee at College of Medical Sciences (Reference number: COMSTH-IRC/2021-62). Convenience sampling method was done. Demographic data like age and sex were noted. In the radiograph, the subpubic angle was measured using the program Digimizer Image Analysis Software. The collected data were analysed using the Statistical Package for the Social Sciences version 20. Point estimate at 95\% Confidence Interval was calculated along with mean and standard deviation for continuous data.

Results: Among 332 pelvic radiographs studied, the mean subpubic angle was found to be $120.42 \pm 22.27^{\circ}$ (118.02-122.81 at 95\% Confidence Interval). The subpubic angle in females was $137.96 \pm 12.47^{\circ}$ and that in males was $101.10 \pm 12.56^{\circ}$.

Conclusions: Our findings are similar to those of other studies, with a minor variation. The subpubic angle was comparatively higher in females than males in the present study. The findings of this study may be of interest to forensic scientists and obstetricians.

Keywords: gender; pelvic bones; radiology; sex determination by skeleton.

\section{INTRODUCTION}

The subpubic angle (SPA) is an angle between the inferior rami of pubic bones and below the symphysis pubis. ${ }^{1}$ The forensic investigation of unidentified human remains begins with the identification of sex. The pelvic bones are the most precise bone for determining sex. ${ }^{2}$ Within the bony pelvis, SPA is one of the important parameters in sex differentiation. Sex estimate using SPA is highly accurate..$^{3,4}$

The size of the birth canal is determined by the size of the SPA, which is a significant criterion in vaginal delivery. Determining the normal range of SPA in different populations would undoubtedly aid obstetrics in the prediction of obstructed labor and, hence, minimize maternal mortality by considering rational treatment plans. Despite the anthropological and obstetric importance of the subpubic angle, only a few studies exist in the Nepalese population.

Therefore, the study aimed to find out the mean subpubic angle in the patient visiting the department of radiodiagnosis of a tertiary care hospital of Nepal.

Correspondence: Dr Ruku Pandit, Department of Anatomy, College of Medical Sciences and Teaching Hospital, Bharatpur, Chitwan, Nepal. Email: ruukuu_252@yahoo.com, Phone: +977. 9817245121. 
Pandit et al. Mean Subpubic Angle of Patients Visiting Department of Radiodiagnosis of a Tertiary Care Hospital: A Descriptive...

\section{METHODS}

This was a descriptive cross-sectional study conducted in the Department of Anatomy of a tertiary care hospital from March to August, 2021. After obtaining clearance from the Institutional Review Committee of College of Medical Sciences and Teaching Hospital (Reference number: COMSTH-IRC/2021-62), we collected digital pelvic radiographs of patients visiting the department of radiodiagnosis. Digital radiographs of patients with hip fracture (traumatic or pathological) or misalignment at the inferior margin of the pubic bones at the pubic symphysis were excluded. Convenience sampling method was used in our study.

Sample size was calculated by the following formula:

$\mathrm{n}=\mathrm{Z}^{2} \times \sigma^{2} / \mathrm{e}^{2}$

$=(1.96)^{2} \times(16.28)^{2} /(2)^{2}$

$=255$

Where,

$\mathrm{n}=$ minimum required sample size

$\mathrm{Z}=1.96$ at $95 \%$ Confidence Interval (Cl)

$\sigma=$ Standard deviation calculated from maximum and minimum values

$\mathrm{e}=$ margin of error

However, we have included digital pelvic radiographs of 332 patients in the study. The demographic data like age and sex were also noted. All the patients were categorized into three different age groups: 18-35, 3650 and above 50 .

All of the pelvic radiographs were taken according to standard anteroposterior (AP) pelvic radiograph protocols. ${ }^{5}$ The radiograph was taken in the anteroposterior view with the big toes contacting on their medial sides (femur in internal rotation of $10-15^{\circ}$ ) at a routine object film distance of $5 \mathrm{~cm}$ and a focal film distance of $92 \mathrm{~cm}$. The SPA was measured on a digital radiograph using the program Digimizer Image Analysis Software.

For SPA, two tangent lines were drawn along the inferior border of the pubic rami. The SPA represents the angle formed by the intersection of these two lines. After the measurement in the software, the data was analyzed by using Statistical Package for the Social Science version 20. Point estimate at $95 \%$ Confidence Interval was calculated along with mean and standard deviation of SPA in males and females and in different age groups of the study participants.

\section{RESULTS}

In this study, we examined pelvic radiographs of 332 patients, out of which the mean SPA was $120.42 \pm 22.27^{\circ}$ (118.02-122.81 at 95\% Confidence Interval), among them $158(47.59 \%)$ were males and $174(52.40 \%)$ were females (Table 1).

\begin{tabular}{|llll|}
\hline $\begin{array}{l}\text { Table } \\
\text { 332). }\end{array}$ & Subpubic angle in males and females $(n=$ \\
\hline Sex & Maximum & Minimum & Mean \pm SD \\
Male & $127.42^{\circ}$ & $70.06^{\circ}$ & $101.10 \pm 12.56^{\circ}$ \\
Female & $167.77^{\circ}$ & $101.01^{\circ}$ & $137.96 \pm 12.47^{\circ}$ \\
Total & $167.77^{\circ}$ & $70.06^{\circ}$ & $120.42 \pm 22.27^{\circ}$ \\
\hline
\end{tabular}

The mean age of male patients was $44.01 \pm 17.35$ years and female patients was $44.39 \pm 16.60$ years while the mean age of overall patient was $44.21 \pm 16.94$ years. The age group 18-35 had the most patients, both male and female, followed by the age groups 3650 in males and above 50 in females. The age group above 50 in males and 36-50 in females had the lowest number of patients. The SPA of three age groups were $104.40 \pm 12.48^{\circ}, 101.08 \pm 12.30^{\circ}$ and $97.59 \pm 12.56^{\circ}$ respectively in males, while in females, the SPA was $141.08 \pm 14.60^{\circ}, 138.86 \pm 9.87^{\circ}$ and $133.78 \pm 12.47^{\circ}$ respectively in the three age groups.

The SPA diminishes with increase in age in both sexes (Table 2).

\begin{tabular}{|c|c|c|c|}
\hline Gender & Age (years) & n (\%) & Mean \pm SD \\
\hline \multirow[t]{3}{*}{ Male } & $18-35$ & 59 (37.34) & $104.40 \pm 12.48^{\circ}$ \\
\hline & $36-50$ & $44(27.84)$ & $101.08 \pm 12.30^{\circ}$ \\
\hline & $>50$ & 55 (34.81) & $97.59 \pm 12.56^{\circ}$ \\
\hline \multirow[t]{3}{*}{ Female } & $18-35$ & 65 (37.35) & $141.08 \pm 14.60^{\circ}$ \\
\hline & $36-50$ & $50(28.73)$ & $138.86 \pm 9.87^{\circ}$ \\
\hline & $>50$ & $59(33.90)$ & $133.78 \pm 12.47^{\circ}$ \\
\hline
\end{tabular}

\section{DISCUSSION}

In our study, the subpubic angle was greater in females than that in males. In both forensic and archaeological contexts, determining a biological profile from the skeleton is important. When skeletal remains are discovered, one of the first things an anthropologist looks for is the gender of an individual. The skull is the first bones of choice with the accuracy of $80-90 \%{ }^{6}$ If the skull is not available, the next bone considered is the pelvic bone. ${ }^{7}$ Sex of the pelvis can be estimated with the accuracy of $70 \%$ using single pelvic parameter whereas, combined use of multiple parameters could give the accuracy of $90 \%$ or more. ${ }^{8}$ The SPA is a significant criterion in sex distinction in the bony pelvis. The SPA is morphologically distinct in male and female, the shape being " $U$ " in female and " $V$ " in male..$^{8-10}$ The pelvis responsiveness to sex hormones 
Pandit et al. Mean Subpubic Angle of Patients Visiting Department of Radiodiagnosis of a Tertiary Care Hospital: A Descriptive...

causes it to grow in the region of the ischium and pubis during puberty and adolescence, resulting in a wider pelvic outlet, an elongated pubis, and a more obtuse SPA in female, ${ }^{11}$ explaining the sexual dimorphism in the shape of SPA.

Traditional use of the cut-off value of $90^{\circ}$ to differentiate the pelvis in males and females (SPA $>90^{\circ}$ indicative of female, while SPA $<90^{\circ}$ indicative of male $)^{3}$ is widely accepted. However, several studies have shown the value of SPA coincides in males and females. ${ }^{12-14}$ In a present study, the SPA in male was $101.10 \pm 12.56^{\circ}$ which is way higher than $90^{\circ}$. Khodeary, et al. and Kayastha $\mathrm{P}$, et al. also found higher SPA $\left(102.31 \pm 12.50^{\circ}\right.$ and $104.72 \pm 10.47^{\circ}$ respectively) than the most accepted cut-off value in male. ${ }^{15,16}$ Mohad Ali SH, et al. discovered SPA in female was $87.4 \pm 6.5^{\circ}$ using a threedimensional computed tomography model of the pelvis, which is less than the widely accepted cut-off value in female. ${ }^{3}$ Hence, the sex determination using the cut-off value of $90^{\circ}$ is not always accurate and may not be applicable to all the population.

In our study, the SPA was $137.96 \pm 12.47^{\circ}$ in females, whereas males had SPA of $101.10 \pm 12.56^{\circ}$. The findings of the present study are comparable with that of Kayastha $P$, et al. (SPA of male $=104.72 \pm 10.47^{\circ}$, SPA of female $\left.=137.15 \pm 11.92^{\circ}\right)$, who also attempted to determine the SPA using digital pelvic radiographs in the Nepalese population as in our study. ${ }^{16}$ On the other hand, the SPA was considerable lower in other studies; $59.05 \pm 7.11^{\circ}$ in males and $75.60 \pm 9.81^{\circ}$ in females in a morphometric study performed on 40 adult dry articulated pelvis ${ }^{1}$ and $68.6 \pm 7.6^{\circ}$ in males and $87.4 \pm 6.5^{\circ}$ in females in a study done in reconstructed threedimensional computed tomography pelvic model in a Malaysian population. ${ }^{3}$ Discrepancies in SPA made by our study in comparison with other studies may be due to variation in the modalities adopted in measuring SPA and different ethnic groups. The SPA in females was higher than in males in the current study. Similar findings were observed in several other studies. ${ }^{1,15,16}$

The subpubic concavity does not fully develop in females until they reach the age of 20 years. ${ }^{8}$ As a result, there is no sexual dimorphism in the preadolescent pelvis. ${ }^{2}$ Therefore, the present study was conducted on adults. The SPA diminishes with increase in age in both males and females in the current study. The distance between the ischial tuberosities of the pelvis decreases with age as the pelvis responds to the pelvis-spine balancing system. ${ }^{17}$ In this agerelated adaptation process, the bi-tuberous diameter narrows, resulting in a reduced SPA in older people. ${ }^{18}$ In a similar study by Kayastha $P$, et al. a weak negative relationship was present between age and SPA, i.e. SPA declines as people age. ${ }^{16}$ Akhlaghi $M$, et al. also noted a significant decrease in SPA with an increase in age in females. ${ }^{19}$ However, Karakas HM, et al. did not find any correlation between the SPA and age, ${ }^{20}$ while Nwoha reported that the older individuals have lager SPA compared to the younger ones. ${ }^{21}$

Determination of SPA to access the sufficiency of the pelvic outlet before delivery can lower the likelihood of maternal death due to obstructed labor in the developing nations. ${ }^{22}$

Studies have showed variation of SPA among ethnic group. ${ }^{14,19}$ However, the present study did not take ethnicity into account. Hence, the result of the study cannot be applied to the overall Nepalese population.

\section{CONCLUSIONS}

Our findings are similar to those of other studies, with a minor variation. The SPA was comparatively higher in females than males in the present study. Skeletal features reveal sexual dimorphism in populations, necessitating population-specific standards.

Conflict of Interest: None.

\section{REFERENCES}

1. Sachdeva K, Singla RK, Kalsey G. Role of Subpubic Angle in Sexual Dimorphism and its Clinical Importance: A Morphometric Study in Adult Human Bony Pelvis. Int J Anat Res. 2016;4(4):3166-9. [Full Text | DOI]

2. Krogman WM, Iscan MY. The human skeleton in forensic medicine, Charles C. Thomas, Springfield, IL. 1987 Sep:202-8. [Full Text $\mid \underline{\text { DOI] }}$

3. Mohd Ali SH, Omar N, Shafie MS, Nik Ismail NA, Hadi $\mathrm{H}$, Nor FM. Sex estimation using subpubic angle from reconstructed three-dimensional computed tomography pelvic model in a contemporary Malaysian population. Anat Cell Biol. 2020 Mar;53(1):27-35. [PubMed | Full Text | DOI]
4. Mohammed RA, Awad KA. Association of Subpubic Angle Measurement with Age and Gender in a Group of Adult Sudanese Patients. Sudan Journal of Medical Sciences. 2020 Sep;15(3):281-9. [Full Text | DOI]

5. Lim SJ, Park YS. Plain Radiography of the Hip: A Review of Radiographic Techniques and Image Features. Hip Pelvis. 2015 Sep;27(3):125-34. [ubMed | Full Text | DOI]

6. Igbigbi PS, Nanono-Igbigbi AM. Determination of sex and race from the subpubic angle in Ugandan subjects. Am J Forensic Med Pathol. 2003 Jun;24(2):168-72. [uued | Full Text | DOI]

7. Schultz AH. The skeleton of the trunk and limbs of higher 
Pandit et al. Mean Subpubic Angle of Patients Visiting Department of Radiodiagnosis of a Tertiary Care Hospital: A Descriptive...

primates. Human Biology. 1930 Sep;2(3):303-438. [․ㅏll Text]

8. Phenice TW. A newly developed visual method of sexing the os pubis. Am J Phys Anthropol. 1969 Mar;30(2):297-301. [PubMed | Full Text | DOI]

9. Duric M, Rakocevic Z, Donic D. The reliability of sex determination of skeletons from forensic context in the Balkans. Forensic Sci Int. 2005 Jan 29;147(2-3):159-64. [PubMed | Full Text $\mid \underline{\text { DOI] }}$

10. Listi GA, Bassett HE. Test of an alternative method for determining sex from the os coxae: applications for modern Americans. J Forensic Sci. 2006 Mar;51(2):248-52. [PubMed | Full Text | DOI]

11. Washburn SL. Sex differences in the pubic bone. Am J Phys Anthropol. 1948 Jun;6(2):199-207. [마bMed | Full Text | DOI]

12. Torimitsu S, Makino Y, Saitoh H, Sakuma A, Ishii N, Yajima D, et al. Morphometric analysis of sex differences in contemporary Japanese pelves using multidetector computed tomography. Forensic Sci Int. 2015 Dec;257:530. e1-530.e7. [PubMed | Full Text | DOI]

13. Decker SJ, Davy-Jow SL, Ford JM, Hilbelink DR. Virtual determination of sex: metric and nonmetric traits of the adult pelvis from 3D computed tomography models. J Forensic Sci. 2011 Sep;56(5):1107-14. [PubMed | Full Text | DOI]

14. Oladipo GS, Ugboma HAA, Suleiman YA. Comparative study of the sub-pubic angles of adult Ijaws and Igbos. Asian Journal of Medical Sciences. 2009 Sep;1(2):26-9. [Full Text]

15. Khodeary MF, Sharaf El-Din AA, Abd-El-hameed SY, Mohamed AA, Thabet HZ. Determination of subpubic angle in Egyptian Population. Mansoura Journal of Forensic Medicine and Clinical Toxicology. 2009 Jan;17(1):41-53. [Full Text]

16. Kayastha P, Suwal S, Shrestha L, Paudel S, Shrestha SL, Joshi
P. Measurement of Subpubic Angle in Radiograph. Nepalese Journal of Radiology. 2020;10(2):22-5. [Full Text | DOI]

17. Moes NC. Variation in sitting pressure distribution and location of the points of maximum pressure with rotation of the pelvis, gender and body characteristics. Ergonomics. 2007 Apr;50(4):536-61. [uuㄹ | Full Text | DOI]

18. Kolesova O, Kolesovs A, Vetra J. Age-related trends of lesser pelvic architecture in females and males: a computed tomography pelvimetry study. Anat Cell Biol. 2017 Dec;50(4):265-74. [ubMed | Full Text | DOI]

19. Akhlaghi M, Bakhttavar K, Mokhtari T, Mehdizadeh F, Parsa VA, Farahani MV, et al. Using Subpubic Angle in Sex Determination and Stature Estimation: An Anthropometric Study on Iranian Adult Population. International Journal of Medical Toxicology and Forensic Medicine. 2017;7(4):195-202. [Full Text]

20. Karakas HM, Harma A, Alicioglu B. The subpubic angle in sex determination: anthropometric measurements and analyses on Anatolian Caucasians using multidetector computed tomography datasets. J Forensic Leg Med. 2013 Nov;20(8):1004-9. [PubMed | Full Text | DOI]

21. Nwoha PU. The anterior dimensions of the pelvis in male and female Nigerians. Afr J Med Med Sci. 1995 Dec;24(4):329-35. [PubMed]

22. Kassebaum NJ, Bertozzi-Villa A, Coggeshall MS, Shackelford KA, Steiner C, Heuton KR, et al. Global, regional, and national levels and causes of maternal mortality during 1990-2013: a systematic analysis for the Global Burden of Disease Study 2013. Lancet. 2014 Sep 13;384(9947):980-1004. [PubMed | Full Text | DOI]

\section{The Author(s) 2022}

This work is licensed under a Creative Commons Attribution 4.0 International License. The images or other third party material in this article are included in the article's Creative Commons license, unless indicated otherwise in the credit line; if the material is not included under the Creative Commons license, users will need to obtain permission from the license holder to reproduce the material. To view a copy of this license, visit http://creativecommons.org/licenses/by/4.0/ 